undetectable antibody concentrations to determine whether they are protected.

This study was supported by funds from the National Fund for Research into Crippling Diseases and the Medical Research Council. We are grateful to our volunteers for their continued co-operation; and to the staff of the staff health clinic (nursing) and the department of nursing personnel at St Thomas's Hospital and Mrs P Prior, Hospital for Sick Children, for their help.

Requests for reprints should be sent to JEB.

\section{References}

${ }^{1}$ Horstmann DM. Controlling rubella: problems and perspectives. Ann Intern Med 1975;83:412-7.

2 Balfour HH, Amren DP. Rubella, measles and mumps antibodies following vaccination of children. A potential rubella problem. $A m \mathcal{F}$ Dis Child 1978;132:573-7.

${ }^{3}$ Balfour HH. Rubella reimmunisation now. Am $\mathcal{f}$ Dis Child 1979;133: $1231-3$.

${ }^{4}$ Herrmann KL, Halstead SB, Wiebenga NH. Rubella antibody persistence after immunization. $\mathcal{F} A M A \quad 1982 ; 247: 193-5$.

${ }^{5}$ Zealley $\mathrm{H}$, Edmond E. Rubella screening and immunisation of schoolgirls: results six to seven years after vaccination. $\mathrm{Br} M e d \mathcal{F} 1982 ; 284: 382-4$.

${ }^{6}$ Hillary IB, Griffith AH. Persistence of antibody 10 years after vaccination with Wistar RA27/3 strain live attenuated rubella vaccine. $\mathrm{Br}$ Med $\mathcal{F}$ $1980 ; 280: 1580-1$
'Best JM, Harcourt GC, Druce A, et al. Rubella immunity by four different techniques; results of challenge studies. $\mathcal{F}$ Med Virol 1980;5:239-47.

${ }^{8}$ Best JM, Banatvala JE, Bowen JM. New Japanese rubella vaccine: comparative trials. $\mathrm{Br} \mathrm{Med}$ f 1974 ;iii :221-4.

9 Marshall WC, Peckham CS, Darby CP, et al. Further studies with rubella vaccines in adults and children. Practitioner 1971;207:632-8.

${ }^{10}$ Kurtz JB, Mortimer PP, Mortimer PR, et al. Rubella antibody measured by radial haemolysis. Characteristics and performance of a simple screening method for use in diagnostic laboratories. F Hyg 1980;84: 213-22.

"Sugishita C, O'Shea S, Best JM, et al. Rubella serology by solid-phase radioimmunoassay: its potential for screening programmes. Clin Exp Immunol 1978;31:50-4.

${ }^{12}$ Dudgeon JA, Marshall WC, Peckham CS, et al. Clinical and laboratory studies with rubella vaccines in adults. $\mathrm{Br} \mathrm{Med} \mathcal{F} 1969$;i :271-6.

${ }^{13}$ Best JM, Harcourt GC, O'Shea S, et al. Rubella vaccines. Lancet 1979;ii: $690-1$.

${ }^{14}$ Harcourt GC, Best JM, Banatvala JE. Rubella-specific and nasopharyngeal antibodies in volunteers with naturally acquired and vaccine-induced immunity after intranasal challenge. F Infect Dis 1980;142:145-55.

${ }^{15}$ MacDonald H, Tobin JO'H, Cradock-Watson JE, et al. Antibody titres in women six to eight years after the administration of RA27/3 and Cendehill rubella vaccines. $\mathcal{f}$ Hyg 1978;80:337-46.

${ }^{16} \mathrm{O}$ 'Shea S, Parsons G, Best JM, et al. How well do low levels of rubella antibody protect? Lancet 1981 ;ii:1284.

${ }^{17}$ Balfour HH, Groth KE, Edelman CK, et al. Rubella viraemia and antibody responses after rubella vaccination and reimmunisation. Lancet 1981 ; : 1078-80.

(Accepted 8 fune 1982)

\title{
Indium-111 autologous leucocyte scanning: comparison with radiology for imaging the colon in inflammatory bowel disease
}

\author{
S H SAVERYMUTTU, A M PETERS， H J HODGSON，V S CHADWICK，J P LAVENDER
}

\begin{abstract}
Indium-111 autologous leucocyte scanning was compared with barium enema for assessing the extent of colonic disease in Crohn's colitis and ulcerative colitis. Scanning was shown to be as accurate as conventional radiology in colitis, reliably distinguishing active from inactive disease.
\end{abstract}

The results suggest that ${ }^{111}$ In-leucocyte scanning is an accurate, non-invasive, alternative technique for imaging the extent of disease in colitis.

\section{Introduction}

A rapid and effective isotopic method of visualising inflamed bowel might offer advantages over conventional radiological techniques in medical and surgical gastroenterology. Initial promising results with ${ }^{99 \mathrm{~m}} \mathrm{Tc}$-diethylenetriamine penta-acetic acid could not be repeated in later studies. ${ }^{12}$ Though ${ }^{67} \mathrm{Ga}$ citrate has been used successfully in ulcerative colitis, ${ }^{3}{ }^{4}$ its value appears to be both limited ${ }^{4}$ and unpredictable ${ }^{5}$ in Crohn's

\footnotetext{
Royal Postgraduate Medical School, Hammersmith Hospital, London W12 0HS

S H SAVERYMUTTU, BSC, MRCP, research fellow in gastroenterology A M PETERS, MD, research fellow in diagnostic radiology

H J HODGSON, DM, MRCP, consultant physician

V S CHADWICK, MD, FRCP, consultant physician

J P LAVENDER, FRCPED, FRCR, consultant radiologist
}

disease. Indium-111-labelled leucocyte scanning is now established as an effective method of locating sepsis, ${ }^{6-9}$ and in preliminary studies we and others have shown that it can image inflamed bowel. ${ }^{1011}$ We have therefore examined the imaging potential of ${ }^{111} \mathrm{In}$-leucocyte scanning in ulcerative colitis and Crohn's colitis as compared with radiology.

\section{Patients and methods}

We studied 20 patients with colitis (see table). In all cases the diagnosis was confirmed histologically. Spread to the small bowel in patients with Crohn's disease was excluded by barium follow-through. From clinical and histological assessment, 17 patients had active colitis and three inactive disease. Colonoscopy was available within two weeks of the scan in six patients (three with active and all three with inactive disease). Nine patients were receiving treatment in the form of steroids or sulphasalazine at the time of the scan.

Radiology-Double-contrast barium enema was performed in 19 patients. The remaining patient was considered too ill for the procedure and the extent of disease was assessed by late barium followthrough films and confirmed by surgery. The extent of colitis was assessed by the radiologist performing the barium study (who was unaware of the result of the leucocyte scan) and classified according to regional disease, regions 1,2 , and 3 corresponding to descending, transverse, and ascending colon, respectively. Radiology was performed within two weeks of the leucocyte scan in 17 patients. In the remaining three barium enema was performed three to four months before the scan.

Scanning-Leucocytes were labelled either in saline with ${ }^{111}$ In-acetylacetonate (eight patients) ${ }^{12}$ or in plasma with ${ }^{111}$ In-tropolonate (12 patients). ${ }^{13}$ Abdominal scans were performed within four 
hours of reinjection of the labelled cells with a gamma camera (IGE $400 \mathrm{~T}$ ) fitted with a medium-energy parallel-hole collimator and assessed by an experienced nuclear physician, who was unaware of the clinical details or radiological assessment. The extent of abnormal activity in early scans corresponding to regions 1,2 , and 3 was determined for each patient.

\section{Results}

The table gives the clinical details and extent of colitis as assessed by radiology, colonoscopy, surgery, and early leucocyte scans. All patients with inactive colitis had negative scans (fig 1). Early scans were abnormal, showing colonic localisation in all cases of active colitis (figs 2-4). Later scans showed disappearance of activity from the initial site of localisation. Steroids and sulphasalazine did not prevent localisation.

There was complete agreement between radiology and scan in 17 of the 20 patients. In three patients the scan disagreed with the extent of disease as assessed by barium enema. In case 7 the scan showed colitis confined to transverse and descending colon, whereas radiology indicated pancolitis. Colonoscopy 10 days after steroid treatment showed disease in the transverse and descending colon. In case 12 both scan and barium enema showed colitis in the descending colon. Additionally, however, radiology showed a skip lesion affecting the midtransverse colon. The skip lesion was missed in the scan on initial assessment but was visible in retrospect. In the third patient (case 8) scanning suggested pancolitis, whereas barium enema indicated disease of ascending and transverse colon only. Colonoscopy showed active pancolitis.

Clinical details, labelling methods, and assessment of extent of colitis

\begin{tabular}{|c|c|c|c|c|c|c|c|c|}
\hline \multirow[b]{2}{*}{ Case No } & \multirow[b]{2}{*}{ Diagnosis } & \multirow{2}{*}{$\begin{array}{l}\text { Clinical } \\
\text { assessment }\end{array}$} & \multirow[b]{2}{*}{ Treatment } & \multirow{2}{*}{$\begin{array}{l}\text { Labelling } \\
\text { method }\end{array}$} & \multicolumn{4}{|c|}{ Regions of colon detected as inflamed* } \\
\hline & & & & & $\begin{array}{l}\text { Barium } \\
\text { enema }\end{array}$ & Scan & Colonoscopy & Surgery \\
\hline $\begin{array}{l}1 \\
2 \\
3\end{array}$ & $\begin{array}{l}\text { Ulcerative colitis } \\
\text { Ulcerative colitis } \\
\text { Ulcerative colitis }\end{array}$ & $\begin{array}{l}\text { Active } \\
\text { Active } \\
\text { Active }\end{array}$ & $\begin{array}{l}\text { Steroids } \\
\text { Sulphasalazine } \\
\text { Steroids, } \\
\text { sulphasalazine }\end{array}$ & $\begin{array}{l}\text { Tropolonate } \\
\text { Tropolonate } \\
\text { Acetylacetonate }\end{array}$ & $\begin{array}{l}1,2,3+ \\
1,2,3+ \\
1,2,3\end{array}$ & $\begin{array}{l}1,2,3 \\
1,2,3 \\
1,2,3\end{array}$ & & $1,2,3$ \\
\hline $\begin{array}{l}4 \\
5 \\
6 \\
7\end{array}$ & $\begin{array}{l}\text { Ulcerative colitis } \\
\text { Ulcerative colitis } \\
\text { Ulcerative colitis } \\
\text { Crohn's disease }\end{array}$ & $\begin{array}{l}\text { Active } \\
\text { Active } \\
\text { Active } \\
\text { Active }\end{array}$ & Steroids & $\begin{array}{l}\text { Acetylacetonate } \\
\text { Acetylacetonate } \\
\text { Acetylacetonate } \\
\text { Acetylacetonate }\end{array}$ & $\begin{array}{l}1,2,3 \\
1,2,3 \\
1,2,3 \\
1,2,3 \ddagger\end{array}$ & $\begin{array}{r}1,2,3 \\
1,2,3 \\
1,2,3 \\
1,2\end{array}$ & 1,2 & $1,2,3$ \\
\hline $\begin{array}{l}8 \\
9\end{array}$ & $\begin{array}{l}\text { Ulcerative colitis } \\
\text { Ulcerative colitis }\end{array}$ & $\begin{array}{l}\text { Active } \\
\text { Active }\end{array}$ & $\begin{array}{l}\text { Sulphasalazine } \\
\text { Steroid, } \\
\text { sulphasalazine }\end{array}$ & $\begin{array}{l}\text { Tropolonate } \\
\text { Tropolonate }\end{array}$ & $\begin{array}{l}2,3 \ddagger \\
1,2\end{array}$ & $\begin{array}{r}1,2,3 \\
1,2\end{array}$ & $1,2,3$ & \\
\hline $\begin{array}{l}10 \\
11 \\
12 \\
13 \\
14 \\
15 \\
16 \\
17 \\
18 \\
19 \\
20\end{array}$ & $\begin{array}{l}\text { Crohn's disease } \\
\text { Crohn's disease } \\
\text { Crohn's disease } \\
\text { Crohn's disease } \\
\text { Crohn's disease } \\
\text { Crohn's disease } \\
\text { Crohn's disease } \\
\text { Ulcerative colitis } \\
\text { Ulcerative colitis } \\
\text { Ulcerative colitis } \\
\text { Ulcerative colitis }\end{array}$ & $\begin{array}{l}\text { Active } \\
\text { Active } \\
\text { Active } \\
\text { Active } \\
\text { Active } \\
\text { Active } \\
\text { Active } \\
\text { Active } \\
\text { Inactive } \\
\text { Inactive } \\
\text { Inactive }\end{array}$ & $\begin{array}{l}\text { Steroids } \\
\text { Steroids }\end{array}$ & $\begin{array}{l}\text { Tropolonate } \\
\text { Tropolonate } \\
\text { Acetylacetonate } \\
\text { Tropolonate } \\
\text { Tropolonate } \\
\text { Tropolonate } \\
\text { Tropolonate } \\
\text { Tropolonate } \\
\text { Acetylacetonate } \\
\text { Acetylacetonate } \\
\text { Tropolonate }\end{array}$ & $\begin{array}{l}1,2 \\
1,2 \\
1,2 \ddagger \\
1,2 \\
1,2 \dagger \\
1,2 \\
1 \\
1 \\
0 \\
0 \\
0\end{array}$ & $\begin{array}{r}1,2 \\
1,2 \\
1 \\
1,2 \\
1,2 \\
1,2 \\
1 \\
1 \\
0 \\
0 \\
0\end{array}$ & $\begin{array}{l}\text { Inactive } \\
\text { Inactive } \\
\text { Inactive }\end{array}$ & 1,2 \\
\hline
\end{tabular}

* Region 1, descending colon; region 2, transverse colon; region 3, ascending colon.

$\dagger$ Barium enema performed more than two weeks before scan.

$\ddagger$ Scan disagreed with extent assessed by barium enema.

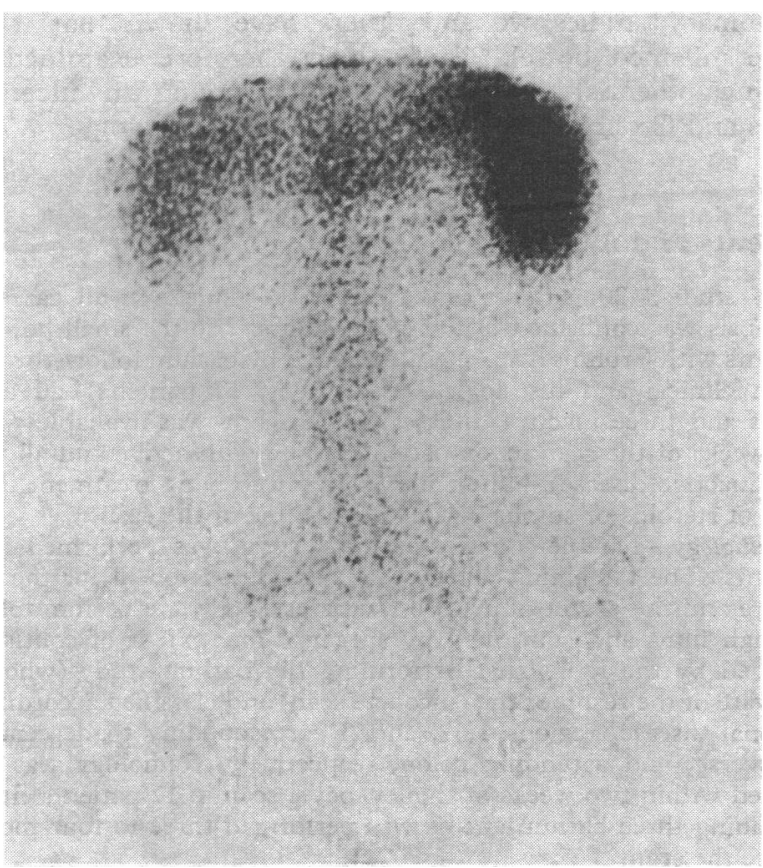

FIG 1-Indium-111-leucocyte scan (at three hours) from patient (case 18) with inactive ulcerative colitis showing normal distribution of activity in spleen, liver, and bone marrow.

\section{Discussion}

Indium-111-leucocyte scanning provides an accurate method of assessing the extent of colitis and reliably distinguishes active from inactive disease. It is non-invasive, requires no bowel preparation, and so is safe in severely ill patients in whom conventional imaging with barium enema and colonoscopy might be hazardous. ${ }^{14}$ We have successfully used ${ }^{11}$ In-leucocyte scanning to identify ischaemic colitis, pseudomembranous colitis, and colitis due to graft-versus-host disease at a time when patients were too ill for conventional radiology.

Indium-111-leucocyte scanning offers several important advantages over the currently available radionuclide ${ }^{6}{ }^{7} \mathrm{Ga}$-citrate. Images are obtained earlier with ${ }^{11}$ In-leucocytes (as early as one hour after reinjection of the cells), whereas with ${ }^{67} \mathrm{Ga}$-citrate images cannot be reliably interpretated for 24 or 48 hours. Furthermore, ${ }^{67} \mathrm{Ga}$-citrate is normally excreted into the bowel, giving rise to false-positive results. ${ }^{15}$ Both ${ }^{67} \mathrm{Ga}$-citrate and ${ }^{111}$ In-leucocyte scanning are established as effective methods for abscess detection. With ${ }^{67} \mathrm{Ga}$-citrate, however, the distinction between abscess and inflamed bowel can be difficult, as in both cases activity remains at the original site in later scans. With 111 In-leucocyte scanning distal transit of activity occurs with inflamed bowel, whereas with abscesses activity remains at the original site. Another advantage of ${ }^{111}$ In-leucocyte scanning is that faecal excretion of the labelled cells can easily be measured and correlates with the disease activity.

In two cases scanning underestimated the extent of disease as assessed by radiology. Both scans were performed with cells 
labelled in saline, which we now think give poorer images than cells labelled in plasma. ${ }^{16}$ Colonoscopy was available in one of these cases and agreed with the scan result. Nevertheless, between the scan and endoscopy the patient was given high-dose steroid treatment, which may have altered the extent of colitis. In the other discrepancy between scan and radiology colonoscopy confirmed the scan estimate. A major theoretical objection to ${ }^{111}$ In-leucocyte scans for assessing inflammatory bowel disease is

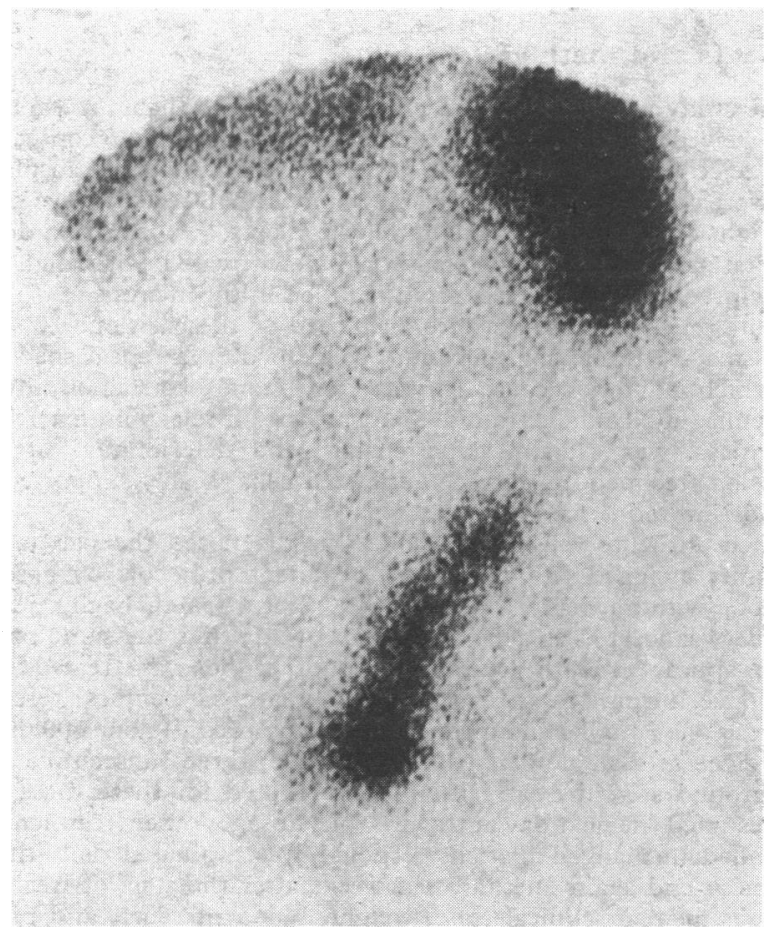

FIG 2-Indium-111-leucocyte scan (at three hours) from case 16 showing localised disease of descending colon corresponding to distal colitis.

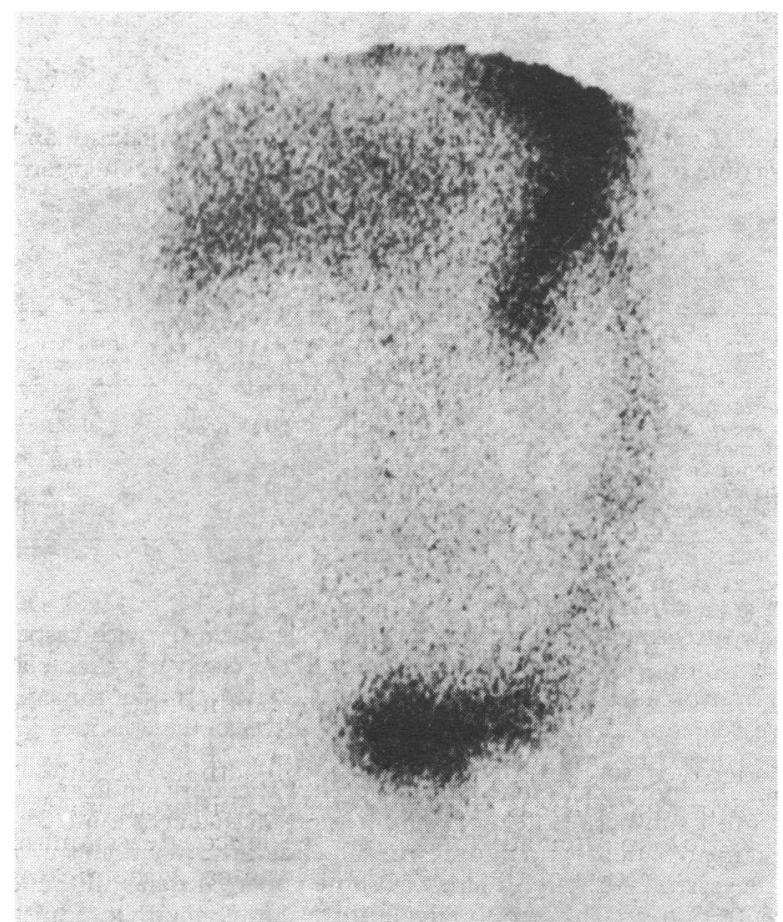

FIG 3-Indium-111-leucocyte scan (at three hours) from case 9 showing continuous disease from rectum to distal transverse colon in patient with ulcerative colitis.
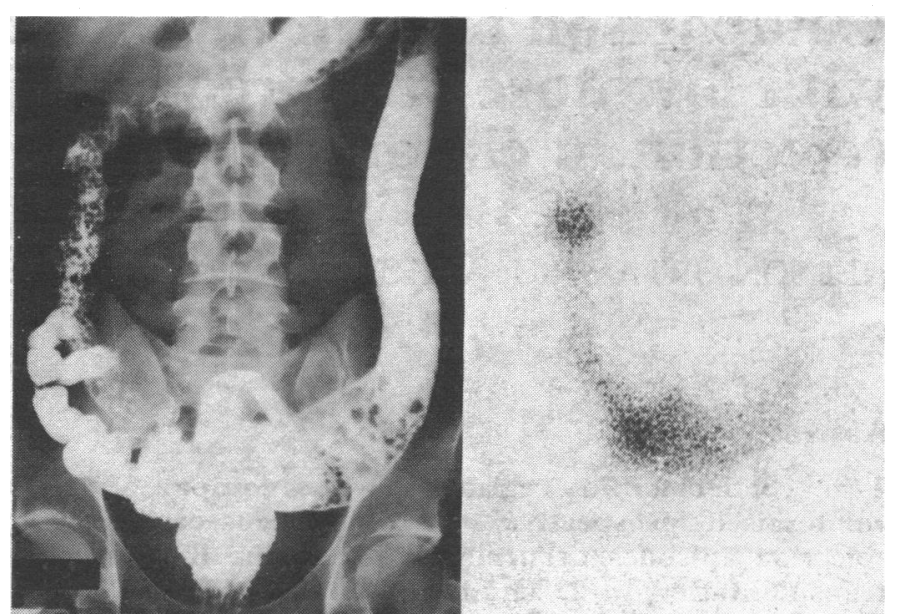

FIG 4-Late barium follow-through film and 111-In-leucocyte scan (at three hours) from case 3 showing pancolitis.

the widespread use of steroids and sulphasalazine for the condition. Both drugs inhibit neutrophil mobility in vitro ${ }^{17}$ and it has been suggested that steroid treatment might give rise to negative results. We did not have any false-negative scans due to steroid or sulphasalazine.

From our experience it seems that ${ }^{111}$ In-leucocyte scanning is a simple, non-invasive technique of imaging the extent of disease in colitis. Its diagnostic accuracy is equal to that of doublecontrast barium enema.

SHS is supported by the Wellcome Trust, and AMP by the Cancer Research Campaign. Indium-111 was supplied by Amersham International. We are grateful to $S$ Barnes for expert secretarial help.

\section{References}

${ }^{1}$ Kadir S, Strauss W. Evaluation of inflammatory bowel disease with 99m-Tc DTPA. Radiology 1979;130:443-6.

${ }^{2}$ Van Aardenne YT, Winter WA, Veredgaal WP, Talonis WK. Detection of inflammatory bowel disease with 99m-Tc DTPA. Diagn Imaging 1980; 49:334-8.

${ }^{3}$ Jones B, Abbruzzese AA, Hill TC, Adelstein SJ. Gallium-67 citrate scintigraphy in ulcerative colitis. Gastrointest Radiol 1980;5:267-72.

4 Rheingold OJ, Tedesco FJ, Block FE, Maldoanado A, Miale A. Gallium67 citrate scintiscanning in active inflammatory bowel disease. Dig Sci $1979 ; 24: 363-8$

${ }^{5}$ Goldenberg DJ, Russel CD, Mihas AA, Dubrovsky EV, Logic JR. Value of gallium-67 citrate scanning in Crohn's disease. $\mathcal{F}$ Nucl Med 1979;20: 215-8.

6 Segal AW, Arnot RW, Thakur ML, Lavender JP. Indium-111 leucocytes for localisation of abscesses. Lancet 1976;ii:1056-8.

${ }^{7}$ McDougall IR, Baumert JE, Lantieri RI. Evaluation of 111-In leucocyte whole body scanning. AfR 1979;133:849-54

8 Ascher NZ, Forstrom L, Simmons RL. Radiolabelled autologous leucocyte scanning for abscess detection. World f Surg 1980;4:395-402.

9 Carrol B, Silverman PM, Goodwin DA, McDougall IR. Ultrasonography and indium-111 white blood cell scanning for the detection of intraabdominal abscesses. Radiology 1981 ; 140:155-60.

10 Saverymuttu SH, Peters AM, Lavender JP, Hodgson HJ, Chadwick VS. Imaging diseased bowel with 111-indium labelled leucocytes. Brf Radiol $1981 ; 54: 707$.

${ }^{11}$ Segal AW, Ensell J, Munro JD, Sarner M. Indium-111 tagged leucocytes in the diagnosis of inflammatory bowel disease. Lancet 1981 ;ii:230-2.

12 Sinn H, Sylvester DJ. Simplified cell labelling with indium-111 acetylacetone. Br $\mathcal{F}$ Radiol 1979;52:758-9.

${ }^{13}$ Danpure HJ, Osman S, Brady F. The labelling of blood cells in plasma with 111-tropolonate. Br $\mathcal{F}$ Radiol 1982;55:247-9.

14 Whorwell PJ, Isaacson PJ. Toxic dilatation of colon in Crohn's disease. Lancet 1981 ;ii:1334-7.

15 Caffee JH, Watts G, Mena I. ${ }^{67}$ Gallium citrate scanning in the diagnosis of intraabdominal abscess. Am $\mathcal{F}$ Surg 1977;133:665-9.

16 Peters AM, Saverymuttu SH, Danpure HJ, Osman S, Lavender JP, Chadwick VS. Granulocyte kinetics: isolation and labelling in plasma abolishes lung sequestration. Clin Sci 1982;62:6P-7P.

17 Rhodes JM, Bartholomew TC, Jewell DP. Inhibition of leucocyte motility by drugs in ulcerative colitis. Gut $1981 ; 22: 648-53$.

(Accepted 4 June 1982) 